\title{
EVALUATION OF IDIOPATHIC SCOLIOSIS BY ANTERIOR AND POSTERIOR ARTHRODESIS
}

\author{
AVALIAÇÃO DO TRATAMENTO DA ESCOLIOSE IDIOPÁTICA POR ARTRODESE POR \\ VIA ANTERIOR E POSTERIOR
}

\section{EVALUACIÓN DEL TRATAMIENTO DE LA ESCOLIOSIS IDIOPÁTICA POR ARTRODESIS ANTERIOR Y POSTERIOR}

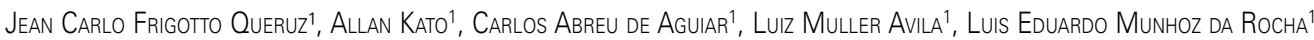

\begin{abstract}
Objective: To evaluate comparatively surgical treatment of adolescent idiopathic scoliosis type 5CN by anterior and posterior approach. Methods: The study consists of a comparative retrospective study of two groups of patients with the thoracolumbar spine arthrodesis technique by anterior and posterior approach. Twenty and two patients were sequentially selected, 11 operated by anterior approach - called Group I - and 11 by posterior approach - Group II. Anamnesis and physical examination were performed, as well as length of hospital stay and ICU stay, degree of correction, comorbidities and pre and postoperative radiographic images data were gathered. Results: The mean age was 13.7 years in Group I and 14 years in Group II. The average hospital stay was 5.81 days for Group I and 5 for Group II. The average ICU stay was 2.81 and 2 days, respectively. Considering the operated levels, Group I presented an average of 4.81 vertebrae (4-6 levels), and Group II presented an average of 6.36 vertebrae (5-11 levels). Complications did not show statistically significant difference. Conclusion: Despite the limited number of patients in groups, it was demonstrated that the posterior approach reduces the number of days of hospitalization and ICU stay. However, it was found increased levels included in the arthrodesis.
\end{abstract}

Keywords: Scoliosis; Spinal fusion; Thoracic vertebrae; Surgical procedures, operative; Adolescent.

\section{RESUMO}

Objetivo: Avaliar comparativamente o tratamento cirúrgico da escoliose idiopática do adolescente tipo $5 \mathrm{CN}$ por abordagem anterior e posterior. Métodos: A pesquisa consta de um estudo retrospectivo comparativo entre dois grupos de pacientes operados pela técnica de artrodese de coluna toracolombar por abordagem anterior e posterior. Foram selecionados sequencialmente 22 pacientes, 11 operados por via anterior - denominado Grupo I - e 11 por via posterior - Grupo II. Realizou-se anamnese e exame físico, assim como foram coletados dados de tempo de permanência hospitalar e em UTI, o grau de correção, as comorbidades e as imagens radiográficas do pré e pós-operatório. Resultados: A média de idade foi de 13,7 anos no Grupo I e de 14 anos no Grupo II. O tempo médio de internação hospitalar foi 5,81 dias para o Grupo I e 5 para o Grupo II. A média de internação em UTI foi de 2,81 e 2 dias, respectivamente. Considerando-se os níveis operados, o Grupo I apresentou média de 4,81 vértebras (4 a 6 níveis), sendo que o Grupo II apresentou média de 6,36 vértebras (5 a 11 níveis). As complicações não apresentaram diferença estatisticamente significativa. Conclusão: Apesar do número limitado de pacientes nos grupos, demonstrou-se que a abordagem posterior diminui o número de dias necessários, tanto em hospitalização, quanto em UTI. Entretanto, constatou-se um aumento dos níveis incluídos na artrodese.

Descritores: Escoliose; Fusão vertebral; Vértebras torácicas; Procedimentos cirúrgicos operatórios; Adolescente.

\section{RESUMEN}

Objetivo: Evaluar comparativamente el tratamiento quirúrgico de la escoliosis idiopática del adolescente del tipo 5CN por abordaje anterior y posterior. Métodos: Consiste en un estudio retrospectivo comparativo de dos grupos de pacientes operados por la técnica de artrodesis toracolumbar, de la columna vertebral por abordaje anterior y posterior. De manera secuencial se seleccionaron 22 pacientes, 11 operados por abordaje anterior - denominado Grupo I - y 11 por abordaje posterior - Grupo II. Se realizaron anamnesis y examen físico, y se recogieron datos de estancia hospitalaria y en la UCl, el grado de corrección, comorbilidades y las imágenes radiográficas pre y postoperatorias. Resultados: La edad media fue 13,7 años en el Grupo I y 14 años en el Grupo II. La estancia hospitalaria para el Grupo / fue de 5,81 días y 5 días para el Grupo II. La estancia media en la UCI fue 2,81 días y 2 respectivamente. Teniendo en cuenta los niveles operados, el Grupo I tenía un promedio de 4,81 vértebras (4-6 niveles), y el Grupo II tuvo un promedio de 6,36 vértebras (5-11 niveles).. No hubo diferencia estadística significativa en las complicaciones. Conclusión: A pesar del número limitado de pacientes en ambos grupos, se demostró que el abordaje posterior disminuye el número de días requeridos tanto en la hospitalización como en la UCl. Sin embargo, se encontró un aumento de los niveles involucrados en la artrodesis.

Descriptores: Escoliosis; Fusión vertebral; Vértebras torácicas; Procedimientos quirúrgicos operativos; Adolescente.

\section{INTRODUCTION}

Adolescent idiopathic scoliosis is defined as a lateral and rotational curve of the spine of at least 10 degrees as measured by the Cobb method. ${ }^{1,2}$

The Scoliosis Research Society (SRS) recommends that idio- pathic scoliosis be classified according to the age of the patient when the diagnosis is made. Infantile scoliosis occurs from birth to 3 years of age, juvenile idiopathic scoliosis between 4 and 10 years of age, and adolescent idiopathic scoliosis from 10 years of age until skeletal maturity. ${ }^{3}$

1. Hospital Pequeno Príncipe, Curitiba, PR, Brazil. 
As its name indicates, the etiology of adolescent idiopathic scoliosis is unknown and described as multifactorial. Various studies have shown that its prevalence is greater among females. ${ }^{2,4-7}$ Generally, diagnosis is made through a process of elimination. ${ }^{2}$

Scoliotic curves progress during growth spurts, but are also capable of progressing in adult life, resulting in serious deformities. ${ }^{8}$ From 1998 to 2003, Wajchenberg et a/ ${ }^{9}$ examined and monitored 100 patients with adolescent idiopathic scoliosis, and prepared a family tree for each of them, using data obtained through interviews. They found a family prevalence of $5.21 \%$ among first-degree relatives and $4.29 \%$ among second degree relatives. The prevalence of curves equal to or greater than 10 degrees, described in the literature, was between $1.2 \%$ and $4.8 \% .^{8}$ Current research on the etiology of idiopathic scoliosis has identified various causative factors, such as genetics, abnormal biomechanical forces, and abnormalities of the connective tissues. ${ }^{10}$ In Brazil, the prevalence ranges from 1.03 to $15.85 \% .^{7,11}$

It is estimated that idiopathic scoliotic curves greater than $10^{\circ}$ occur in $2 \%$ to $4 \%$ of people aged under 16 years, and less than $10 \%$ of those children with curves of $10^{\circ}$ or more require treatment. ${ }^{10}$

The first step to understanding adolescent idiopathic scoliosis is to know how to classify it, making it possible to evaluate a clinical case, estimate a prognosis, ${ }^{12}$ and offer guidance about and compare the different treatment methods. ${ }^{13}$

The first classification for scoliosis was proposed by Schulthess ${ }^{14}$ in 1905-1907. This was followed by several other classifications during the 20th century ${ }^{15}$ until, in 1983, King et a $/^{12}$ proposed a classification that was globally accepted and became widely used to guide scoliosis treatment. This classification is based on the coronal plane and divides thoracic curves into five types, recommending the vertebral level to be fused. In the 1990s, various studies emerged criticizing King's classification because: 1 ) it is not easily reproducible $;^{16}$ 2) it only evaluates curves in the coronal plane: ${ }^{17} 3$ ) it presents errors in the indication of fusion arthrodesis level; ${ }^{18} 4$ ) it is based on arthrodesis with Harrington rods; 5) it does not quantify the lumbar deformity; ${ }^{19}$ and 6 ) it does not cover all types of curves. Aiming to correct these errors, Lenke proposed a new classification based on radiographs of the coronal and sagittal planes with a lumbar deformity quantifier. ${ }^{20}$

The Lenke classification is made up of three components: type of curve (1 to 6); lumbar spine modifier ( $A, B$, or $C$ ), and thoracic sagittal modifier $(-, N,+)$. Lenke established that every patient with scoliosis has three curves (proximal thoracic, main thoracic, and thoracolumbar/lumbar), and that greatest measurement, called the major curve, must be rigid. The other two curves, called the minor curves, can be either flexible, if radiographs of the lateral inclination correct for a value lower than $25^{\circ}$, or rigid, if they do not correct for less than $25^{\circ}$ and/or show kyphosis greater than $20^{\circ} .{ }^{21}$

The second component of the classification relates to the lumbar modifier. To establish it, first pelvic obliquity is corrected, then a vertical line is drawn starting at the center of the sacrum (CSVL) in the coronal radiograph. If this line does not touch the pedicles of the lumbar vertebrae, the curve receives lumbar modifier $A$. If the CSVL intersects with the lumbar vertebral pedicles, it receives lumbar modifier B. If it goes beyond the bony limits of the vertebrae, it receives lumbar modifier C. ${ }^{21}$

The final component of the classification is the sagittal thoracic modifier. To quantify it, the kyphosis between the $5^{\text {th }}$ and $12^{\text {th }}$ thoracic vertebra is measured. If it is less than $10^{\circ}$, it receives the sign -. If it is between $10^{\circ}$ and $40^{\circ}$, it receives the sign $\mathrm{N}$. And if it is greater than $40^{\circ}$, it receives the sign.$+^{21}$

The Lenke classification was evaluated for intraobserver reproducibility, with indices ranging from 0.89 to 0.73 , with an average of 0.78 , which demonstrates good reproducibility (Kappa $>0.75),{ }^{22}$ and for interobserver reproducibility, with indices between 0.74 and 0.62 , with an average of 0.63 , demonstrating reasonable reproducibility $(0.5<$ Kappa $<0.75) .^{23}$

In children and adolescents, surgery is considered if the curve reaches a magnitude that could cause problems in adulthood. ${ }^{4}$
Although most authors recommend surgery when the curve reaches $50^{\circ}$, other factors need to be considered. Lesser lumbar and thoracolumbar curves can cause significant curvature of the spine, coronal decompensation, and cosmetic deformity. Double curves of $50^{\circ}$ are not as cosmetically unacceptable as simple curves and, if progression occurs in skeletally mature patients, it is likely to be gradual. In the immature patient, on the other hand, surgery may be considered for curves between $40^{\circ}$ and $50^{\circ}$, depending on the clinical appearance. Surgery is most likely to be necessary in the patient with a curve that progresses in spite of treatment with orthosis or in a patient who has never received orthotic therapy. ${ }^{4}$

This research is a comparative evaluation of anterior and posterior surgical approaches for adolescent idiopathic scoliosis.

\section{MATERIALS AND METHODS}

This research, approved by the Ethics Committee under number CAAE 15878113.1.0000.0097, is a retrospective, comparative study between two groups of patients who underwent thoracolumbar arthrodesis via anterior and posterior surgical approaches at the Spinal Surgery Service of Hospital Pequeno Príncipe of Curitiba, PR, Brazil. Twenty-two patients with Lenke type 5CN adolescent idiopathic scoliosis, who underwent surgery using these techniques, were chosen consecutively. Of the patients evaluated, 11 had been operated on using anterior approach arthrodesis, called Group I, and 11 using the posterior approach arthrodesis, called Group II. (Figures 1 and 2) A minimum follow-up period of two years was considered. However, the vast majority of the patients selected, even though randomly, had more than two years of follow-up.

All the patients in each group were operated on by the same surgeon using the same surgical technique, consecutively and sequentially.

The patient data were collected from medical reports which included patient history, and pre- and post-operative physical exams. Similarly, radiographs (anteroposterior, profile, and dynamic) taken at various times, from the pre-operative period through to the minimum follow-up period considered in this study, were evaluated. Static and dynamic listhesis, fusion, lysis, alignment, and breakage or loosening of material were assessed. In terms of post-operative
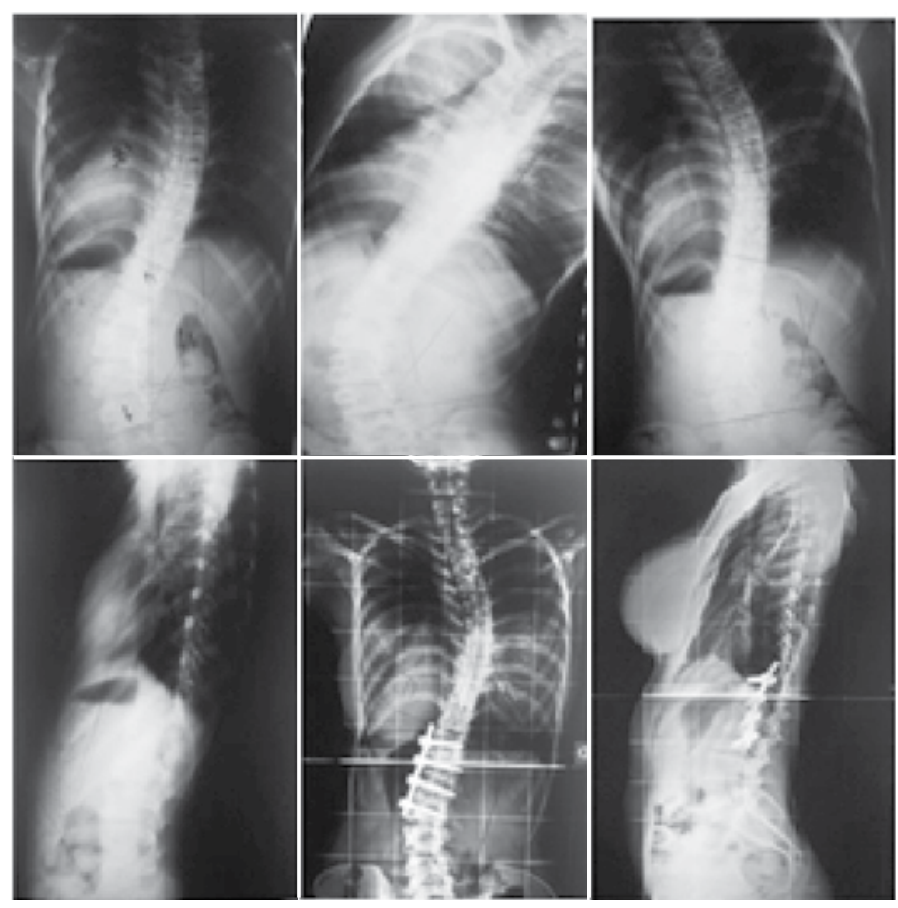

Figure 1. Sequential radiographs in lateral, anteroposterior, and dynamic views in a patient who underwent surgical treatment by the anterior approach. 


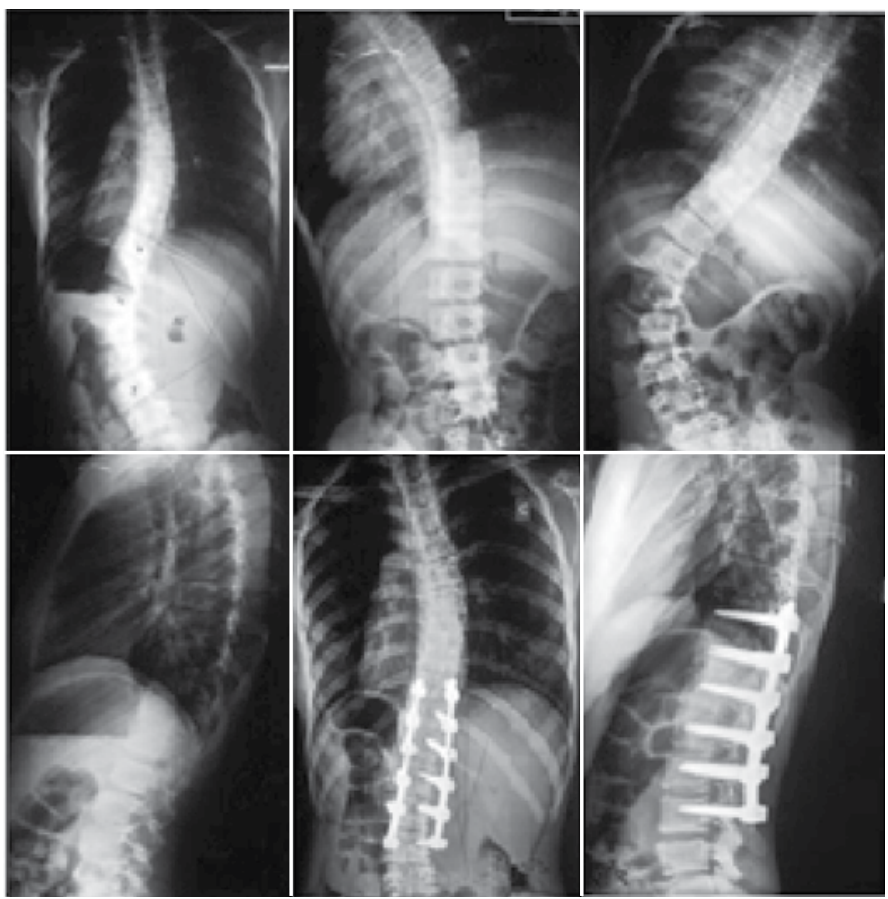

Figure 2. Sequential radiographs in lateral, anteroposterior, and dynamic views in a patient who underwent surgical treatment by the posterior approach.

complications, superficial and deep infections of the surgical wound, systemic comorbidities secondary to the surgical procedure, and death were taken into account.

The inclusion criteria were patients with Lenke type $5 \mathrm{CN}$ adolescent idiopathic scoliosis with a minimum follow-up of 2 years. Exclusion criteria were patients with associated pathologies, and systemic diseases that compromised the surgical region or the surgical outcome (rheumatoid arthritis, lupus erythematosus, and diabetes).

Analysis of the statistical data was performed using Fischer's exact test

\section{RESULTS}

Of the 11 patients selected in Group I (Anterior Approach), 10 (91.1\%) were female and $1(0.9 \%)$ was male, with an average follow-up of 24 months. The average age was 13.7 years, ranging from 12 to 15 years of age. The average hospitalization time was 5.81 days, with an average of 2.81 days in the ICU. In Group II (Posterior Approach), of the 11 patients evaluated, 10 (90.1\%) were female and one $(0.9 \%)$ was male, with an average follow-up of 24 months. The average age was 14 years, ranging from 12 to 17 years of age. The average hospitalization time was 5 days, with 2 days in the ICU.

In terms of the levels operated, Group I had an average of 4.81 fused vertebrae (4-6 levels with arthrodesis) and Group II had an average of 6.36 fused vertebrae (5-11 levels with arthrodesis).

Complications in Group I included one case of broken material (rod), with good clinical and radiographic evolution, not requiring re-intervention. There was another case that developed pseudoarthrosis in L2-L3 and underwent a new surgical arthrodesis procedure via the posterior approach. In Group II, no complications were observed during the follow-up period.

\section{DISCUSSION}

The treatment of simple, structured, lumbar and thoracolumbar curves in patients with adolescent idiopathic scoliosis has been a subject of debate. The anterior approach technique, with screws inserted into the vertebral bodies and a compression cable, was first advocated by Dwyer ${ }^{24}$ in 1968 and had good coronal correction documented in various articles. ${ }^{22-26}$ However, the kyphotizing effect, poor derotation, and an unacceptable rate of pseudoarthrosis were documented in subsequent follow-up. ${ }^{22}$

To remedy poor derotation, Zielke ${ }^{27}$ added another $3.2 \mathrm{~mm}$ rod by the anterior approach. Better coronal correction was noted, with an improvement in derotation aspects as compared to Dwyer's original cable. ${ }^{28-31}$ Subsequent analyses of these reports showed the uniformity of the kyphotizing effect of the anterior compression of the convex side with these devices and, once again, a relatively high incidence of pseudoarthrosis. ${ }^{32}$

The advent of solid rods marked a new generation of anterior instrumentation for lumbar and thoracolumbar scoliosis. The combination of anteriorly placed solid rods with structured intervertebral grafts (femoral rings or titanium cages) enabled the creation or maintenance of lordosis in the lumbar and thoracolumbar spine together with satisfactory coronal and axial correction. However, traces of pseudoarthrosis were maintained. ${ }^{33,34}$ The addition of double rod instrumentation appeared to resolve this issue. ${ }^{35}$

Hall's concept ${ }^{36}$ of a very short construction (3 or 4 segments) with hypercorrection of the apex, produced excellent coronal results. Great flexibility is essential for the successful implementation of this approach. The kyphotizing effect on these segments is still an issue, there being no reported cases of pseudoarthrosis. ${ }^{32}$

Anterior approach instrumentation and fusion for idiopathic scoliosis became popular with the introduction of Harrington instrumentation, ${ }^{37}$ but new instrumentation systems emerged, such as that of Cotrel-Dubousset, offering advantages of better frontal and sagittal correction and promoting primary stability. ${ }^{38}$

Posterior instrument was further strengthened by the subsequent replacement of hooks by pedicle screws as vertebral anchors, enabling greater corrections to be achieved. ${ }^{39}$

The comparison between posterior instrumentation using pedicle screws and anterior approach using thoracolumbar and lumbar correction systems has been being debated for years. ${ }^{40-42}$

Defenders of posterior access state that posterior release with pedicle screws maintains lumbar lordosis with a simple approach, similar correction, and vertebral fusion. ${ }^{32,43}$

Similarly, defenders of the anterior approach state that fewer levels of fusion are required, achieving better correction in the frontal plane. ${ }^{43}$

In this research, we analyzed the case histories of 22 patients, allocated to two different groups according to the type of surgical procedure performed to correct curvature of the spine due to adolescent idiopathic scoliosis, classified as Lenke type 5CN: Group I (Technique of thoracolumbar spinal arthrodesis via anterior approach) and Group II (Technique of thoracolumbar spinal arthrodesis via the posterior approach).

The number of individuals was the same for both groups (11 patients in each group). The average age at the time of the surgery in Group I was 13.72 years (12 to 15 years) and in Group II, it was 14 years (11 to 17 years).

In terms of the reduction of the scoliotic curve in degrees, there was a reduction of $11^{\circ}$ in Group I and $50^{\circ}$ in Group II, correlating to an average percentage reduction in Group I of 63\% and in Group II of $77 \%$. (Table 1)

Table 1. Descriptive analyses between Group I and Group II

\begin{tabular}{c|c|c}
\hline Descriptive analyses & Group I & Group II \\
\hline Average age at the time of surgery & 13,72 & 14 \\
\hline Age range at the time of surgery & $(15-12)$ & $(17-11)$ \\
\hline Average reduction of the angle in degrees & $11^{\circ}$ & $50^{\circ}$ \\
\hline Range of the reduction of the angle in degrees & $(27 \%-84 \%)$ & $(67 \%-88 \%)$ \\
\hline Average percentage of reduction & $63 \%$ & $77 \%$ \\
\hline Average number of vertebrae fused & 4.81 & 6.3 \\
\hline Range of the number of vertebrae fused & $(4-6)$ & $(5-11)$ \\
\hline
\end{tabular}


A descriptive analysis of the groups shows that the average reduction of the angle in degrees and the average percentages of reduction are higher in Group II. This data suggests that the groups may have had different performances, and if this hypothesis is statistically proven, it can be confirmed that Group II is superior to Group I (Figure 3).

Verifying the frequency of the percentages of correction:

It can be seen that Group I has only four individuals with Scoliotic Curve Correction percentages higher than 70\%, while in Group II there are nine.

Therefore, the null hypothesis is that Groups I and II do not demonstrate a significant difference in the percentage of correction of the scoliotic curve, and the alternative hypothesis is that there is a significant difference between the groups in this regard.

To verify the assumptions listed, we decided to use the non-parametric statistical technique called Fischer's exact test. The free statistical software R was used for the analyses.

It was confirmed that with a p-value of 0.0805 and a confidence interval of $95 \%$, there was no significant difference between the two types of intervention surgery in terms of the percentage of corrective reduction of the scoliotic curvature.

An evaluation of the possible differences between the groups by the number of fused vertebrae is represented graphically in Figure 4.

It can be confirmed that most of the procedures for Group I had indications for arthrodesis of between four and five vertebrae, whereas most of the Group II, indications were for fusion of between five and eight vertebrae. Once again, the differences between Group I and Group II are evident.

Analyzing the number of vertebrae that underwent arthrodesis using Fischer's exact test, a p-value of 0.02374 was obtained, indicating a significant difference between the numbers of fused vertebrae for the two groups.

The other variables were compared between the groups, including the percentage of correction of the scoliotic curvature (with a

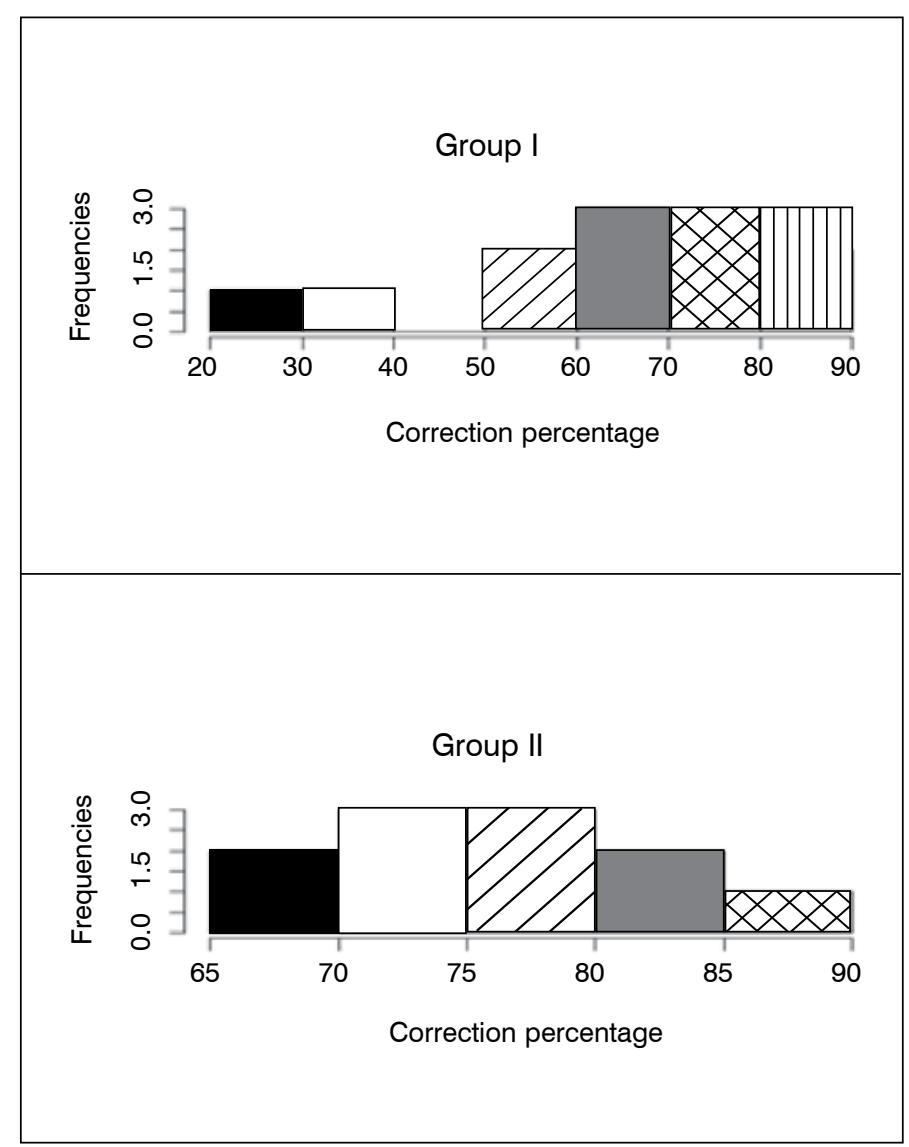

Figure 3. Percentage of correction of the scoliotic curve in groups I and II.

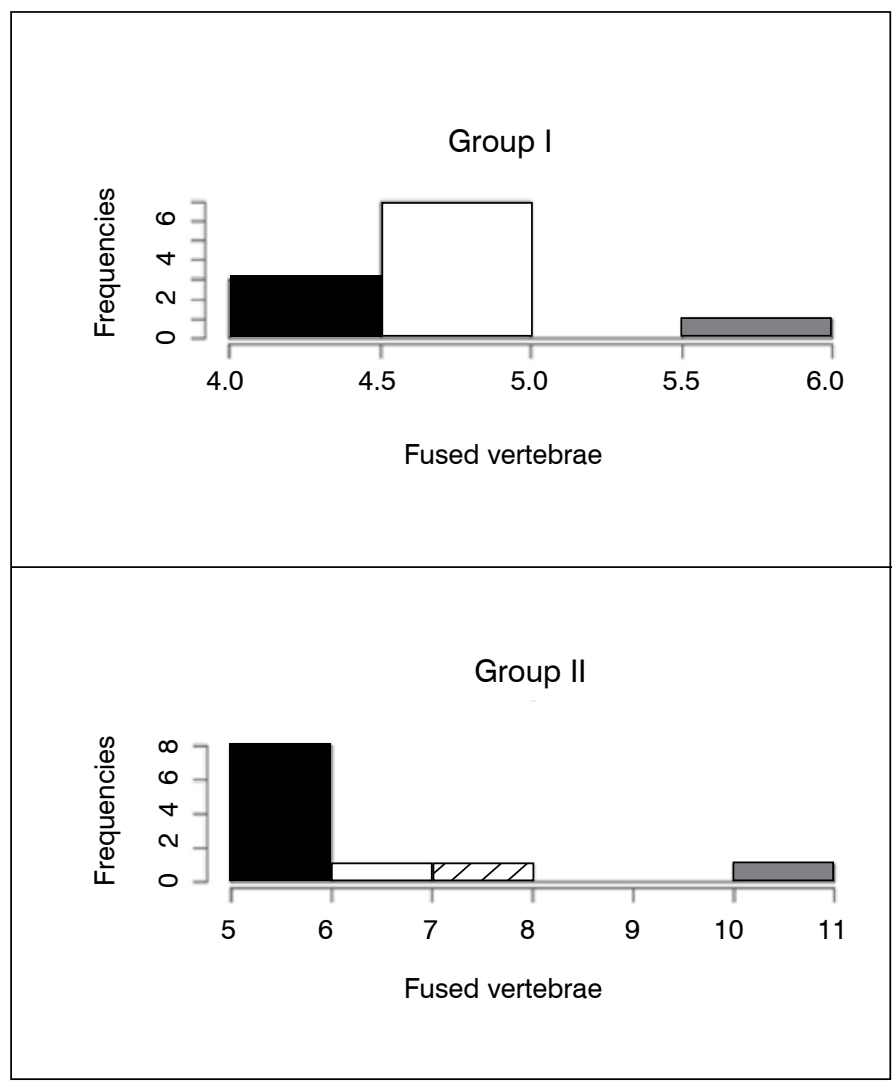

Figure 4. Frequency of the number of fused vertebrae in Groups I and II.

referential benchmark of $70 \%$ ), number of days in the ICU, number of days in the hospital, and comorbidities.

The same results were obtained for number of days in the ICU and number of days in the hospital. In both tests, there was sufficient statistical evidence, at a 95\% confidence interval, to assume that the surgical intervention procedure using anterior approach spinal arthrodesis differed significantly from the method of posterior approach spinal arthrodesis, both for days in the ICU and days of hospitalization. Based on the averages of the variables in tests, it can be assumed that the posterior method of spinal arthrodesis results in less hospitalization time and a shorter time in ICU, and consequently would be the more indicated technique from this perspective.

As regards comorbidity, Fischer's exact test produced a p-value of 0.4762 , much greater than the critical p-value of 0.05 . Therefore, the test proved that there was no significant difference between the surgical procedures, when compared by the presence of comorbidity.

\section{CONCLUSION}

Despite the limited number of patients, the comparative study of surgical treatments for Lenke type $5 \mathrm{CN}$ adolescent idiopathic scoliosis via the anterior and posterior surgical approaches did not present significant results for the reduction of the angle of the curvature for either of the procedures. Evaluating the other available variables, better performance was identified for the posterior approach spinal arthrodesis method in terms of days in the ICU and days of hospitalization, Despite the greater number of fused vertebrae, the patients tended to recover in less time in the anterior approach arthrodesis group.

$\overline{\text { All authors declare no potential conflict of interest concerning }}$ this article. 


\section{REFERENCES}

1. Bunnell WP. Selective screening for scoliosis. Clin Orthop Relat Res. 2005:(434):40-5.

2. Lonstein JE. Adolescent idiopathic scoliosis. Lancet. 1994;344(8934):1407-12.

3. Freeman III BL. Escoliose e cifose. In: Canale, ST. Cirurgia Ortopédica de Campbell Vol. II. Décima Edição. Editora Manole; 2006: 1757-1759.

4. Justice CM, Miller NH, Marosy B, Zhang J, Wilson AF. Familial idiopathic scoliosis: evidence of an X-linked susceptibility locus. Spine (Phila Pa 1976). 2003;28(6):589-94.

5. Alden KJ, Marosy B, Nzegwu N, Justice CM, Wilson AF, Miller NH. Idiopathic scoliosis: identification of candidate regions on chromosome 19p13. Spine (Phila Pa 1976). 2006;31(16):1815-9

6. Wong HK, Hui JH, Rajan U, Chia HP. Idiopathic scoliosis in Singapore schoolchildren: a prevalence study 15 years into the screening program. Spine (Phila Pa 1976). 2005;30(10):1188-96.

7. Bunge EM, Juttmann RE, de Koning HJ. Screening for scoliosis: do we have indications for effectiveness? J Med Screen. 2006;13(1):29-33.

8. Lonstein JE, Winter RB, Moe JH, Bianco AJ, Campbell RG, Norval MA. School screening for the early detection of spine deformities. Progress and pitfalls. Minn Med. 1976;59(1):51-7.

9. Wajchenberg M, Puertas EB, Zatz M. Estudo da prevalência da escoliose idiopática do adolescente em pacientes brasileiros. Coluna/Columna. 2005;4(3):113-68.

10. Weinstein SL. Adolescent idiopathic scoliosis: prevalence and natural history. In Weinstein SL, editor. The pediatric spine: principles and practice. New York: Raven Press; 1994. p. 463-78.

11. Elias N, Teixeira JCM. Escoliose idiopática do adolescente; diagnóstico precoce através de exame ortopédico rotineiro. Rev Bras Ortop. 1992; 27(4):275-7.

12. King HA, Moe JH, Bradford DS, Winter RB. The selection of fusion levels in thoracic idiopathic scoliosis. J Bone Joint Surg Am. 1983;65(9):1302-13.

13. Burstein AH. Fracture classification systems: do they work and are they useful? J Bone Joint Surg Am. 1993:75(12):1743-4.

14. Schulthess W. Die pathologie und therapie der rückgratsverkrümmungen. In: Joachimsthal G. Handbuch der orthopädischen chirurgie. Jena: Gustav Fischer Verlag; 1905-1907.

15. Goldstein LA. The surgical management of scoliosis. Clin Orthop Relat Res. 1964:35:95-115

16. Lenke LG, Betz RR, Bridwell KH, Clements DH, Harms J, Lowe TG, et al. Intraobserver and interobserver reliability of the classification of thoracic adolescent idiopathic scoliosis. J Bone Joint Surg Am. 1998;80(8):1097-106.

17. Bridwell KH, McAllister JW, Betz RR, Huss G, Clancy M, Schoenecker PL. Coronal decompensation produced by Cotrel-Dubousset "derotation" maneuver for idiopathic right thoracic scoliosis. Spine (Phila Pa 1976). 1991;16(7):769-77.

18. Lee CK, Denis F, Winter RB, Lonstein JE. Analysis of the upper thoracic curve in surgically treated idiopathic scoliosis. A new concept of the double thoracic curve pattern. Spine (Phila Pa 1976). 1993;18(12):1599-608.

19. Lenke LG, Bridwell KH, Baldus C, Blanke K, Schoenecker PL. Cotrel-Dubousset instrumentation for adolescent idiopathic scoliosis. J Bone Joint Surg Am. 1992;74(7):1056-67.

20. Lenke LG, Betz RR, Harms J, Bridwell KH, Clements DH, Lowe TG, et al. Adolescent idiopathic scoliosis: a new classification to determine extent of spinal arthrodesis. J Bone Joint Surg Am. 2001;83(8):1169-81.

21. Vialle EN, Vialle LR, Martins Filho DE, Jorge RM. Confiabilidade de uma versão em português da classificação de Lenke para escoliose idiopática do adolescente. Coluna/Columna. 2006:5(2):77-83.

22. Kaneda K, Shono Y, Satoh S, Abumi K. New anterior instrumentation for the management of thoracolumbar and lumbar scoliosis. Application of the Kaneda two-rod system. Spine (Phila Pa 1976). 1996;21(10):1250-61.

23. Ogon M, Giesinger K, Behensky H, Wimmer C, Nogler M, Bach CM, et al. Interobserver and intraobserver reliability of Lenke's new scoliosis classification system. Spine (Phila Pa 1976). 2002;27(8):858-62.
24. Dwyer AF. Experience of anterior correction of scoliosis. Clin Orthop Relat Res. 1973:(93):191-206.

25. Kohler R, Galland O, Mechin H, Michel CR, Onimus M. The Dwyer procedure in the treatment of idiopathic scoliosis. A 10-year follow-up review of 21 patients. Spine (Phila Pa 1976). 1990;15(2):75-80

26. Giehl JP, Völpel J, Heinrich E, Zielke K. Correction of the sagittal plane in idiopathic scoliosis using the Zielke procedure (VDS). Int Orthop. 1992;16(3):213-8.

27. Kaneda K, Fujiya N, Satoh S. Results with Zielke instrumentation for idiopathic thoracolumbar and lumbar scoliosis. Clin Orthop Relat Res. 1986;(205):195-203.

28. Ogiela DM, Chan DP. Ventral derotation spondylodesis. A review of 22 cases. Spine (Phila Pa 1976). 1986;11(1):18-22.

29. Bernstein RM, Hall JE. Solid rod short segment anterior fusion in thoracolumbar scoliosis J Pediatr Orthop B. 1998:7(2):124-31.

30. Hurford RK Jr, Lenke LG, Lee SS, Cheng I, Sides B, Bridwell KH. Prospective radiographic and clinical outcomes of dual-rod instrumented anterior spinal fusion in adolescent idiopathic scoliosis: comparison with single-rod constructs. Spine (Phila Pa 1976). 2006;31(20):2322-8

31. Cochran T, Irstam L, Nachemson A. Long-term anatomic and functional changes in patients with adolescent idiopathic scoliosis treated by Harrington rod fusion. Spine (Phila Pa 1976). 1983;8(6):576-84

32. Geck MJ, Rinella A, Hawthorne D, Macagno A, Koester L, Sides B, et al. Comparison of surgical treatment in Lenke $5 \mathrm{C}$ adolescent idiopathic scoliosis: anterior dual rod versus posterior pedicle fixation surgery: a comparison of two practices. Spine (Phila Pa 1976). 2009;34(18):1942-51.

33. Hsu LC, Zucherman J, Tang SC, Leong JC. Dwyer instrumentation in the treatment of adolescent idiopathic scoliosis. J Bone Joint Surg Br. 1982;64(5):536-41.

34. Lowe TG, Peters JD. Anterior spinal fusion with Zielke instrumentation for idiopathic scoliosis. A frontal and sagittal curve analysis in 36 patients. Spine (Phila Pa 1976). 1993;18(4):423-6.

35. Sweet FA, Lenke LG, Bridwell KH, Blanke KM. Maintaining lumbar lordosis with anterior single solid-rod instrumentation in thoracolumbar and lumbar adolescent idiopathic scoliosis. Spine (Phila Pa 1976). 1999;24(16):1655-62.

36. Dwyer AF, Schafer MF. Anterior approach to scoliosis. Results of treatment in fifty-one cases. J Bone Joint Surg Br. 1974;56(2):218-24.

37. Harrington PR. Treatment of scoliosis. Correction and internal fixation by spine instrumentation. J Bone Joint Surg Am. 1962;44:591-602.

38. Bridwell KH, Betz R, Capelli AM, Huss G, Harvey C. Sagittal plane analysis in idiopathic scoliosis patients treated with Cotrel-Dubousset instrumentation. Spine (Phila Pa 1976). 1990:15(7):644-9.

39. Li M, Ni J, Fang X, Liu H, Zhu X, He S, et al. Comparison of selective anterior versus posterior screw instrumentation in Lenke5C adolescent idiopathic scoliosis. Spine (Phila Pa 1976). 2009:34(11):1162-6.

40. Suk SI, Lee CK, Chung SS. Comparison of Zielke ventral derotation system and CotrelDubousset instrumentation in the treatment of idiopathic lumbar and thoracolumbar scoliosis. Spine (Phila Pa 1976). 1994;19(4):419-29

41. Burton DC, Asher MA, Lai SM. Patient-based outcomes analysis of patients with single torsion thoracolumbar-lumbar scoliosis treated with anterior or posterior instrumentation: an average 5- to 9-year follow-up study. Spine (Phila Pa 1976). 2002;27(21):2363-7.

42. Hee HT, Yu ZR, Wong HK. Comparison of segmental pedicle screw instrumentation versus anterior instrumentation in adolescent idiopathic thoracolumbar and lumbar scoliosis. Spine (Phila Pa 1976). 2007:32(14):1533-42.

43. Halm H, Niemeyer T, Link T, Liljenqvist U. Segmental pedicle screw instrumentation in idiopathic thoracolumbar and lumbar scoliosis. Eur Spine J. 2000;9(3):191-7. 